\title{
F \\ The use of local substrates in the production of legume nodulating bacteria inoculants for Sub- Saharan Africa: Preliminary results
}

\author{
Jyhane Amanda Ngo Mimb1,3, Boyomo Onana22, Laurette Ngo Nkot ${ }^{3}$, Hyppolite Ntede $\mathrm{Nga}^{4}$ and \\ Dieudonne Nwaga ${ }^{* 1,2}$. \\ ${ }_{1}^{1}$ Laboratory of Soil Microbiology, Biotechnology Centre, University of Yaounde I, P. O Box 812 Yaounde, Cameroon. \\ 2 Department of Microbiology, Faculty of Science, University of Yaounde I. P. O Box 812 Yaounde, Cameroon. \\ ${ }^{3}$ Department of Plant Biology, Faculty of Science, University of Douala. P. O Box 24157. Douala, Cameroon. \\ ${ }^{4}$ National Advanced school of engineering, University of Yaounde I, P. O Box 8390. Yaounde-Cameroun \\ *Corresponding author: dnwaga@yahoo.fr
}

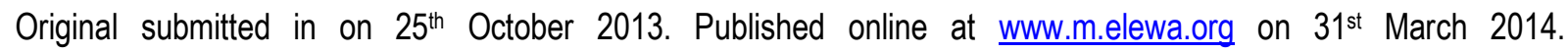
http://dx.doi.org/10.4314/jab.v75i1.2

\begin{abstract}
Objective: The aim is to assess cheaper organic local products as an alternative for legume nodulating bacteria (LNB) inoculants production.

Methodology and results: The study was done using two selected LNB strains (VUID1 and AHYP21), 16 local media ( $C$ and $N$ sources), and groundnuts. The LNB biomass obtained from the local media was greater than the one obtained from the standard YEM media. VUID1 strain had a better yield in sucrose/soybean water, cow milk/yeast extract, cow milk/soybean water than the mannitol/yeast water media; while AHYP21 strain yielded better in the glycerol/yeast water, sucrose/yeast extract, cow milk/yeast extract and cow milk/soybean water media. Local carriers (Forest humus, horticultural compost, palm tree compost, and household organic compost) increased groundnuts growth and nitrogen uptake. These preliminary results showed the potential of local media and carriers in the production of inoculants for leguminous plants.

Conclusions and application of findings: All the local substrates showed an important potential as local culture media and carriers for the production of LNB inoculants. Instead of mannitol and yeast extract, other products can be used for the culture of LNB. The production of LNB inoculants is easy, using organic local matter as carriers of inoculants. LNB inoculants will be more accessible for farmers.
\end{abstract}

Key-words: Carrier, groundnuts, inoculants, legume nodulating bacteria, local media

\section{INTRODUCTION}

The increasing world population needs sustainable crop production to satisfy food demand. Yield increase is of major importance for crop production, specifically in developing countries where population growth is high and chemical fertilizers use is low. Integrated Soil Fertility Management (ISFM) involving microbial fertilizers are recommended for sub-Saharan African countries. In the 90's a program was set up in Cameroon for the selection and the production of effective bio-fertilizers such as mycorrhizal fungi and nitrogen fixing organisms for local agriculture (Nwaga et al., 2000). The production 
and quality of LNB inoculants in many developing countries is limited by the availability of suitable carriers or technological limitations (Khavazi et al., 2007). The first step in the production of legume inoculants is the massive growth of a selected LNB strain in a liquid medium (Thompson, 1991). Then, the LNB culture is transferred into a solid carrier. Most procedures use Yeast Extract Mannitol (YEM) broth for LNB culture (Vincent, 1970, Ferreria and Castro, 2005, Kucuk and Kivanc, 2008, Hashem and A-Moniem, 2010). Both mannitol and yeast extract, carbon and nitrogen sources are expensive ingredients of that medium making it not suitable for industrial production of inoculants (Singh et al., 2011) and not available in many developing countries. Thus, other alternative materials which are able to support good growth of LNB have been developed, include coal, cellulose, filter mud, compost, mineral soils sawdust, sugarcane bagasse,

\section{MATERIAL AND METHODS}

Two LNB strains from the Soil Microbiology Laboratory were used: VUID1 strain isolated from Vigna unguiculata L. and AHYP21 strain isolated from Arachis hypogaea L. The acidic tolerance, efficiency, and morphological aspect of the colonies of these strains have been determined (Nwaga and Ngo Nkot, 1998). Peanut seeds of Bafia town (Centre, Cameroon) are used for the greenhouse experimentation. Different sources of carbon and nitrogen were chosen for assessing the growth of rhizoid strains. They were mannitol, sucrose, glycerol, cow milk (carbon source) and yeast extract, yeast water, soybean water, fish water (nitrogen source). Mannitol, yeast extract, sucrose, and glycerol are provided by the Soil Microbiology Laboratory. Yeast water, fish water and soybean water are prepared in the Laboratory (Somasegaran and Hoben, 1985). Cow's milk and fish meal (to prepare fish water) are purchased on the local market. Fish meal is localy use for the nutrition of animals and it is obtained after drying, crushing and sieving much type of fish. Sixteen media were made with these carbon sugar waste, water hyacinth, vermiculite, and perlite (Crawford and Berryhill, 1983; Kremer and Peterson, 1983; Chao and Alexander, 1984; Graham-Weis et al. 1987; Muniruzzaman and Khan, 1992; Daza et al., 2000; Hashem and A-Moniem, 2010; Singh, 2011). Sugar waste was found to allow a higher growth of LNB in media comparing to YEM standard media used for LNB (Singh et al., 2011). Nevertheless sugarcane waste is not available all the time and its transformation as a carrier is not easy. The results obtained with sugar's waste and sugarcane bagasse show that carrier other than peat could be used for LNB growth and LNB inoculants production. So identifying other available and inexpensive products for LNB growth and LNB inoculants production is of importance for legume technology. The aim of this work is to evaluate local products for culture media and carriers in the production of LNB inoculants for tropical legumes.

and nitrogen sources (Table 1). Yeast water is prepared as follows: dry yeast, $40 \mathrm{~g}$ is suspended in $1000 \mathrm{ml}$ of water. The solution is boiled, decanted, bottled and autoclaved at $121^{\circ} \mathrm{C}$ for 30 minutes (Somasegaran and Hoben, 1985). Fish powder is obtained in the local market and comes from Senegal. It is used in the diet of cattle and sheep. Fish water is prepared as follows: fish meal, $100 \mathrm{~g}$ is suspended in $1000 \mathrm{ml}$ of water. The solution is boiled slowly for 2 hours, replacing the water lost regularly, cooled, centrifuged (5000 rpm for 15 minutes) decanted, bottled and autoclaved at $121^{\circ} \mathrm{C}$ for 30 minutes (Somasegaran and Hoben, 1985). To prepare soybean water, $100 \mathrm{~g}$ of soybean seeds are crushed and mixed with $1000 \mathrm{ml}$ of water. The solution is boiled slowly for 2 hours, replacing the water lost regularly, cooled, centrifuged (5000 rpm for 15 minutes) decanted, bottled and autoclaved at $121^{\circ} \mathrm{C}$ for 30 minutes (Somasegaran and Hoben, 1985). The amounts of carbon and nitrogen are determined on samples of powder fish, yeast extract, cow's milk and soya flour. 
Ngo Mimb et al. J. Appl. Biosci. 2014. Use of local substrates in production of legume nodulating
bacteria inoculants.

Table 1: Composition of sixteen local media used for the growth of rhizoid strains

\begin{tabular}{|c|c|c|c|c|c|c|c|c|c|c|c|c|c|c|c|c|}
\hline \multirow{2}{*}{$\begin{array}{c}\text { For } 11 \\
\text { Elements }\end{array}$} & \multicolumn{16}{|c|}{$\mathrm{N}^{\circ}$ media } \\
\hline & 1 & 2 & 3 & 4 & 5 & 6 & 7 & 8 & 9 & 10 & 11 & 12 & 13 & 14 & 15 & 16 \\
\hline A & 10 & 10 & 10 & 10 & & & & & - & - & - & - & - & - & - & - \\
\hline B & - & - & - & - & 10 & 10 & 10 & 10 & - & - & - & - & - & - & - & - \\
\hline C & - & - & _- & - & _- & _- & _- & _- & 10 & 10 & 10 & 10 & & & & \\
\hline D & - & - & - & - & - & - & - & _- & - & - & - & - & 7 & 7 & 7 & 7 \\
\hline$E$ & 0,5 & - & - & - & 0,5 & - & - & - & 0,5 & - & - & - & 0,5 & - & - & - \\
\hline$F$ & - & 100 & & _- & - & 100 & 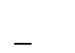 & _- & _ & 100 & & _- & _ & 100 & & _ \\
\hline G & - & - & 100 & - & - & - & 100 & - & _- & - & 100 & - & _- & - & 100 & - \\
\hline $\mathrm{H}$ & _ & _- & - & 100 & _ & _- & _- & 100 & - & _- & _- & 100 & _ & _- & - & 100 \\
\hline$\left.\right|^{*}$ & 1 & 1 & 1 & 1 & 1 & 1 & 1 & 1 & 1 & 1 & 1 & 1 & 1 & 1 & 1 & 1 \\
\hline $\mathrm{J} *$ & 10 & 10 & 10 & 10 & 10 & 10 & 10 & 10 & 10 & 10 & 10 & 10 & 10 & 10 & 10 & 10 \\
\hline $\mathrm{K}^{*}$ & 1 & 1 & 1 & 1 & 1 & 1 & 1 & 1 & 1 & 1 & 1 & 1 & 1 & 1 & 1 & 1 \\
\hline$L^{*}$ & 1 & 1 & 1 & 1 & 1 & 1 & 1 & 1 & 1 & 1 & 1 & 1 & 1 & 1 & 1 & 1 \\
\hline
\end{tabular}

A: mannitol, B : glycerol, C: sucrose, D : cow milk, E: yeast extract, $\mathrm{F}$ : yeast water, G: soybean water, $\mathrm{H}$ : fish water, I : $\mathrm{NaCl}(50$ $\mathrm{mg} / \mathrm{ml}), \mathrm{J}: \mathrm{MgSO}_{4}, 7 \mathrm{H}_{2} \mathrm{O}(10 \mathrm{~g} / \mathrm{l}), \mathrm{K}: \mathrm{CaCl}_{2}(40 \mathrm{~g} / \mathrm{l}), \mathrm{L}: \mathrm{FeCl}_{3}(4 \mathrm{~g} / \mathrm{l}) ;$; : Stock solutions ; the $\mathrm{pH}$ of the media is adjusted to $5,5 \mathrm{using}$ $\mathrm{HCl} \mathrm{N}$ before autoclaving at $121^{\circ} \mathrm{C}$ during $20 \mathrm{~min}$.

The results are contained in table 2. The growth of LNB was assessed by using UV visible spectrophotometer every 24 hours during 4 days. Each strain was tested in 16 growth media (Table 1). For each strain three replicates were made. Four days after inoculating and shaking, LNB culture is centrifuged at $8000 \mathrm{rpm}$ at $4^{\circ} \mathrm{C}$ during $20 \mathrm{~min}$ (Nwaga and Ngo Nkot, 1998). The resulting pellet was weighed to obtain the LNB fresh biomass $(\mathrm{mg} / \mathrm{ml})$. Forest humus, horticultural compost, palm tree compost and household organic compost are sources of organic matter. They are used as carriers for LNB inoculants. Physicochemical analysis is performed to determine the characteristics of these materials (Table 2).

Table 2: Physicochemical characteristics of local substrates used.

\begin{tabular}{|c|c|c|c|c|c|c|c|}
\hline Parameters & OC & $\mathrm{HC}$ & PC & $\mathrm{FH}$ & $\begin{array}{l}\text { Fish } \\
\text { meal }\end{array}$ & $\begin{array}{l}\text { Soybean } \\
\text { meal }\end{array}$ & $\begin{array}{l}\text { Yeast } \\
\text { extract }\end{array}$ \\
\hline Water holding capacity (\%) & 66 & 21 & 97 & 60 & nd & nd & nd \\
\hline Moisture (\%) & 7.0 & 5.0 & 10.7 & 3.9 & nd. & nd. & nd \\
\hline Total organic matter (\%) & 7.0 & 9.0 & 8.0 & 6.5 & nd & nd & nd \\
\hline Carbon (\%) & 4.0 & 5.0 & 4.7 & 3.8 & 7.1 & 7.4 & 2.7 \\
\hline Total Nitrogen (\%) & 0.60 & 0.56 & 1.10 & 0.20 & 4.70 & 5.90 & 7.50 \\
\hline Assimilable P (mg/kg) & 353 & 563 & 503 & 53 & nd & nd & nd \\
\hline $\mathrm{Ca}(\mathrm{cmol} / \mathrm{kg})$ & 11.0 & 4.0 & 2.9 & 2.1 & nd & nd & nd \\
\hline $\mathrm{Mg}(\mathrm{cmol} / \mathrm{kg})$ & 7.0 & 6.0 & 15.5 & 1.5 & nd & nd & nd \\
\hline $\mathrm{K}(\mathrm{cmol} / \mathrm{kg})$ & 0.7 & 0.6 & 0.5 & 0.6 & $\mathrm{nd}$ & nd & nd \\
\hline $\mathrm{Na}(\mathrm{cmol} / \mathrm{kg})$ & 0.5 & 0.6 & 0.3 & 0.1 & nd & nd & nd \\
\hline CEC (cmol/kg) & 27 & 15 & 37 & 9 & nd & nd & nd \\
\hline pH water & 7.0 & 7.4 & 7.5 & 7.4 & nd & nd & nd \\
\hline $\mathrm{pH} \mathrm{KCl}$ & 6 & 7.02 & 6.8 & 6.8 & nd & nd & nd \\
\hline \multicolumn{8}{|c|}{$\begin{array}{l}\text { Inoculants made using local carriers are used to inoculate } \\
\text { groundnuts seeds before planting in } 4 \mathrm{~kg} \text { pots containing } \\
\text { a mixture of poor soil (soil sand mixture; } 1 / 1 \text { : v/v) } \\
\text { pasteurized at } 90{ }^{\circ} \mathrm{C} \text { during } 30 \text { minutes. Organic matter } \\
\text { (OM) was harvested, crushed, dried and sieved to pass } 1\end{array}$} \\
\hline
\end{tabular}


distillated water was added to the $63 \mathrm{~g}$ mixture in aseptic condition to obtain $10 \%$ of humidity $(70 \mathrm{~g})$. For each type of carrier, three replicates were done. Then, $30 \mathrm{ml}$ of the LNB pure culture was added to the $70 \mathrm{~g}$ sterilized humid carrier to obtain a $100 \mathrm{~g}$ of LNB inoculants which is stored at room temperature. To evaluate the influence of the carrier-based inoculants on nitrogen fixation using groundnuts, each type of carrier-based inoculant constitute one treatment. Groundnuts sown in the control were not inoculated. Eighteen plants were used per treatment with three replicates per treatment (54 plants

\section{RESULTS}

Physicochemical characteristics of different substrates: Three representative samples of household organic compost, horticultural compost, palm tree compost, forest humus, fish meal, soybean meal and yeast extract were tested for physicochemical characteristics. Only carbon and nitrogen amounts were determined on soybean meal, fish powder, and yeast (Table 1).

Local substrates as culture media for LNB: LNB growth with the two strains was different in all the sixteen media. The strains did not have the same biomass in the same medium. In the four media with mannitol as carbon source, turbidity and LNB biomass were not the same with the two strains. The two LNB strains had higher turbidity after four days of incubation in the same medium made of mannitol and yeast water $(O D>1.5)$. This was higher than the turbidity in the control medium mannitol/yeast extract. When using sucrose as the carbon source, the optimal growth for VUID1 strain was with sucrose/yeast extract (OD > 1.4). For AHYP21 strain the best medium is sucrose/yeast water $(O D \approx 1.8$. In the presence of glycerol in the medium, VUID1 strain growth begin after twenty-four hour of incubation. The turbidity per treatment). Forty-five plants of groundnuts were harvested forty-five days after sowing at flowering stage. Nodule weight (dry and fresh) and number, plant biomass (dry and fresh) and nitrogen uptake was determined per plant. Number of nodules was determined by counting after groundnuts harvesting. Fresh biomasses (nodules and plants) were determined after harvesting by weighing. Dry biomasses (nodules and plants) were obtained by weighing after drying in an oven at $72^{\circ} \mathrm{C}$ for four days. Nitrogen uptake was evaluated using the Kjeldahl method (Vincent, 1970).

was near 1.2 with glycerol/yeast water. Glycerol/soybean water offers a maximal growth with the same LNB strain (VUID1) after ninety-six hours of incubation $(O D \approx 1.3)$. AHYP21 strain with glycerol/yeast water had a turbidity $\mathrm{OD} \approx 2$. In the media with cow milk as carbon source, the two strains did not use nitrogen sources the same way. VUID1 strain grows rapidly in cow milk/yeast extract (OD 1.2 after $24 \mathrm{~h}$ of incubation). AHYP21 strain use yeast extracts (OD 1.8 four days after incubation) and fish water (OD 1.6 four days after incubation) (Fig 2). Each OD corresponds to an LNB biomass. Some media had a better growth than the standard media for the two strains (72.40 mg of dry matter/ml for AHYP21 strain and 65.20 $\mathrm{mg}$ of dry matter/ml for VUID1 strain). They are mannitol/yeast water $(71.80 \mathrm{mg}$ of dry matter $/ \mathrm{ml})$, sucrose/soybean water $(84.60 \mathrm{mg}$ of dry matter $/ \mathrm{ml})$, cow milk/soybean water $(73.50 \mathrm{mg}$ of dry matter $/ \mathrm{ml})$, cow milk/yeast extract $(80.50 \mathrm{mg}$ of dry matter/ml for VUID1 strain and sucrose/yeast extract $(77.40 \mathrm{mg}$ of dry matter $/ \mathrm{ml})$, glycerol/yeast water $(84.60 \mathrm{mg}$ of dry matter $/ \mathrm{ml})$, cow milk/soybean water $(73.50 \mathrm{mg}$ of dry matter $/ \mathrm{ml})$, cow milk/yeast extract $(73.60 \mathrm{mg}$ of dry matter/ml) for AHYP21 strain.
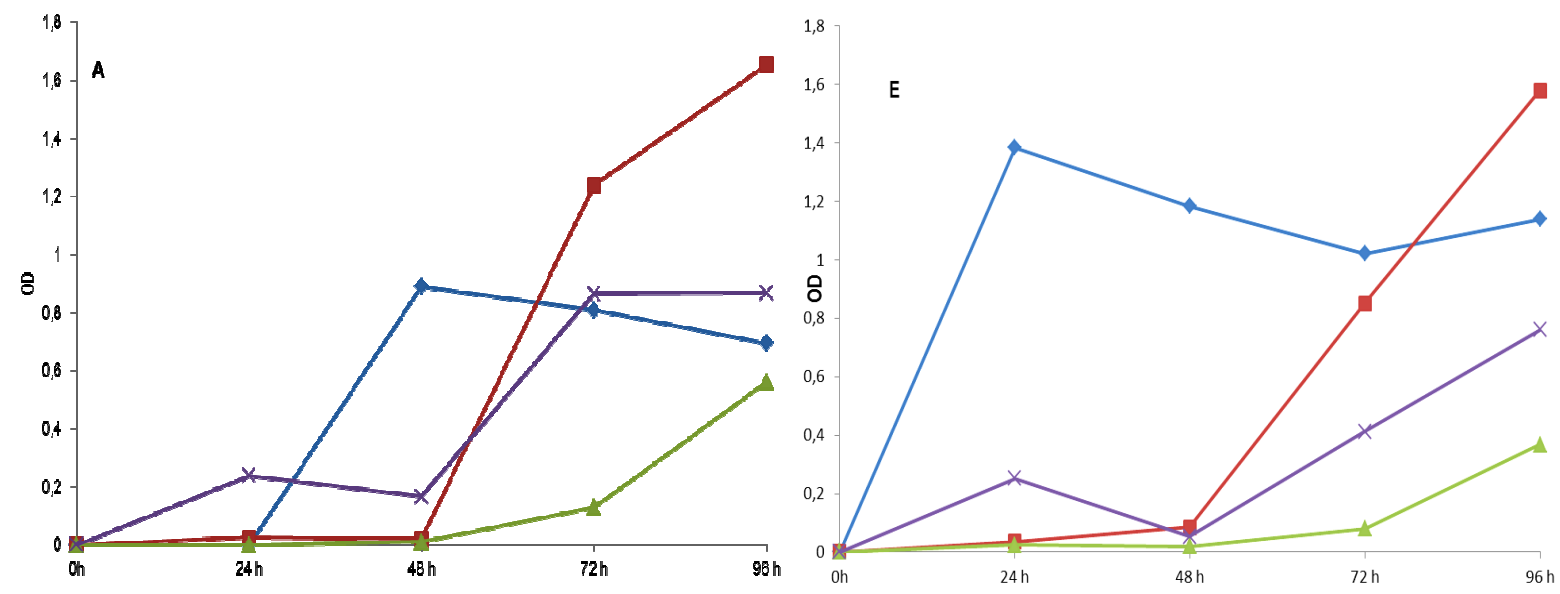

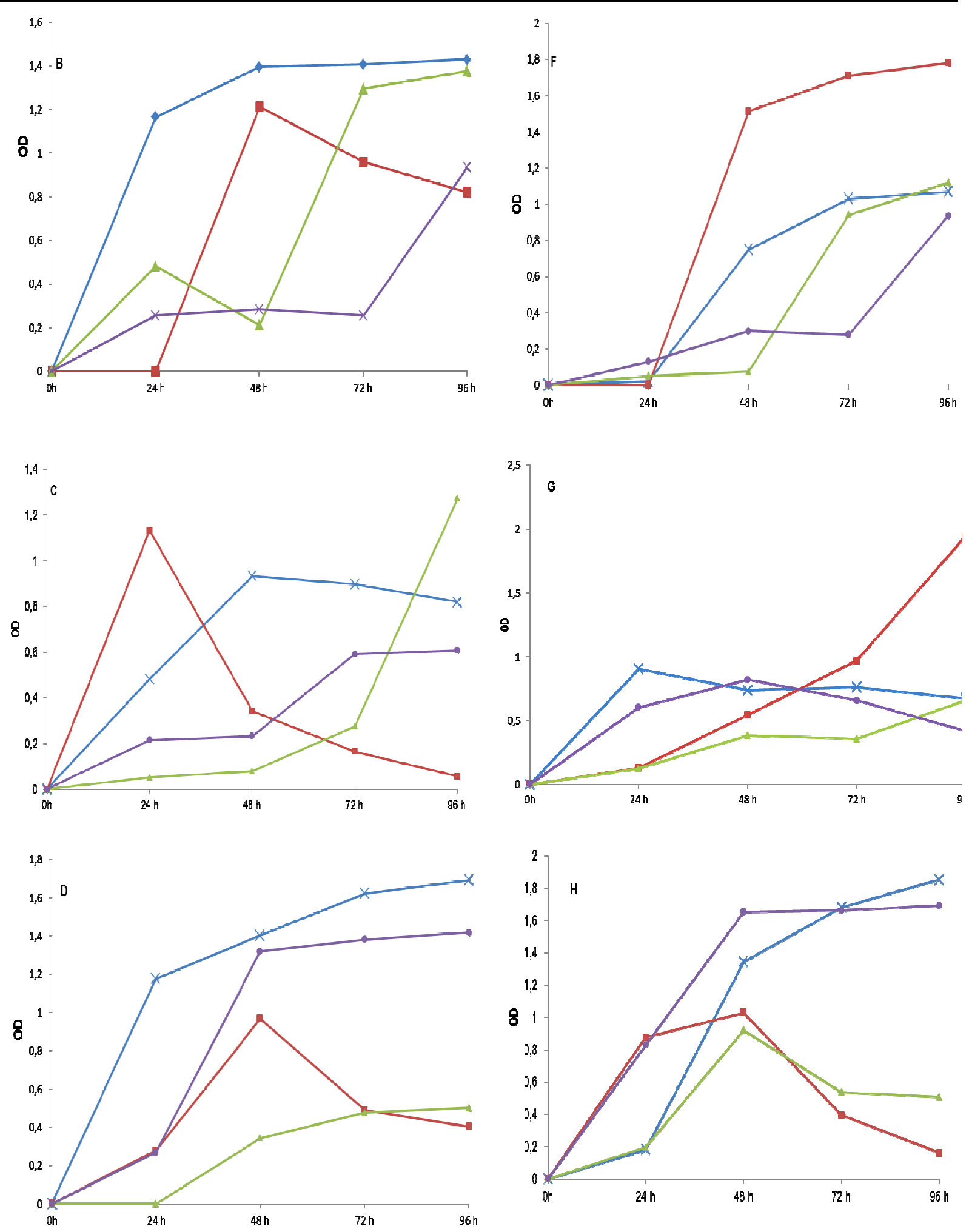

Figure 1: Growth of LNB strains in various culture media. A: mannitol, B: sucrose, C: glycerol and D: cow milk for VUID1 strain and E: mannitol, F: sucrose, G: glycerol, H: cow milk for AHYP21 strain, OD: optical density. Each point is the mean of three replicates. Blue: yeast extract, red: yeast water, indigo: fish water, green: soybean water 
Local substrates as carriers for LNB: The results of nodulation show significant differences between all the treatments. Groundnuts in the control did not have nodules on their roots. There was no significant difference for the number of nodules of groundnuts inoculated with LNB inoculant based on household organic compost and LNB inoculant based on horticultural compost. LNB inoculant based on palm tree compost and forest humus allowed the highest number of nodules (respectively 10.46 nodules/plant and 10.53 nodules/plant). A difference on the dry biomass of nodules between LNB inoculant was noted based on household organic compost $(2.57 \mathrm{mg} / \mathrm{plant})$, LNB inoculant based on horticultural compost (2.07 mg/plant), LNB based on palm tree compost (2,00 mg/plant) and LNB inoculant based on forest humus ( $3.57 \mathrm{mg} / \mathrm{plant})$. With plant biomass, there were significant differences between all the treatments. Dry biomass of groundnuts obtained with the inoculation with the LNB inoculant based on horticultural compost and LNB inoculant based on palm tree compost were equal to the threshold of $5 \%$. Dry biomass of groundnuts is higher for the plants inoculated with the LNB inoculant based on forest humus ( $2.62 \mathrm{~g} /$ plant). The effect of LNB inoculant based carrier is positive in all the treatments but it's higher on the treatment were groundnuts were inoculated with LNB inoculant based on forest humus $(67 \%)$. Nitrogen uptake is $12.25 \mathrm{mg} / \mathrm{plant}$ in the control where groundnuts were un inoculated. Groundnuts inoculated with LNB inoculant based on forest humus have absorbed and an average of $26.46 \mathrm{mg}$ of nitrogen/plant. The effect of nitrogen uptake is positive in all the other treatments. The higher effect is where groundnuts are inoculated with LNB inoculant with forest humus $(127 \%)$ (Table3).

Table 3: Effect of diverse local carriers on LNB efficiency in nitrogen uptake of groundnuts at flowering stage: nodulation, plant biomass and nitrogen uptake.

\begin{tabular}{|c|c|c|c|c|c|c|c|c|}
\hline & \multicolumn{3}{|c|}{ Nodulation } & \multicolumn{3}{|c|}{ Plant biomass } & \multicolumn{2}{|c|}{ Efficiency } \\
\hline $\begin{array}{l}\text { Parameters } \\
\text { Treatments }\end{array}$ & $\mathrm{Nb} /$ plant & FW & DW & FW & DW & $E$ & $\mathbf{N}$ & $E$ \\
\hline $\mathrm{CO}$ & 0 & 0 & 0 & $6.46 \mathrm{a}$ & $1.57 \mathrm{a}$ & 1 & $12.25 \mathrm{a}$ & 1 \\
\hline $\mathrm{OC}$ & $8.13 \mathrm{a}$ & $7.20 \mathrm{~b}$ & $2.57 \mathrm{a}$ & $6.96 \mathrm{ab}$ & $1.79 b$ & 8 & $17.01 \mathrm{~b}$ & 39 \\
\hline $\mathrm{HC}$ & $7.53 a$ & $5.80 a$ & $2.07 \mathrm{a}$ & $7.58 \mathrm{~b}$ & $1.95 \mathrm{c}$ & 24 & $19.50 \mathrm{c}$ & 67 \\
\hline PC & $10.46 \mathrm{~b}$ & $5.60 \mathrm{a}$ & $2.00 a$ & $7.11 \mathrm{ab}$ & $1.83 \mathrm{c}$ & 17 & $18.17 \mathrm{c}$ & 55 \\
\hline $\mathrm{FH}$ & $10.53 \mathrm{~b}$ & $10.00 \mathrm{c}$ & $3.57 \mathrm{~b}$ & $10.18 \mathrm{c}$ & $2.62 d$ & 67 & $24.46 \mathrm{~d}$ & 127 \\
\hline
\end{tabular}

$\mathrm{CO}$ (control), OC (household organic compost), HC (horticultural compost), PC (palm tree compost), FH (forest humus). Different letters in the same column indicates significant difference between treatments at $5 \%$ (Newman - Keuls). FW (fresh weight mg/plant), DW (dry weight mg/plant), E (effect\%), N (Nitrogen uptake $\mathrm{mg} /$ plant).

\section{DISCUSSION}

Effect of local substrates on LNB growth: LNB strains VUID1 and AHYP21 do not use carbon and nitrogen sources the same way in the different media. VUID1 strain prefers media with mannitol/yeast water, sucrose/yeast extract, glycerol/soybean water, cow milk/yeast extract and cow milk/yeast water. VUID1 strain prefers these media as compare to standard medium. AHYP21 strain prefers media with mannitol/yeast water, sucrose/yeast water, glycerol/yeast water and cow milk/fish water. VUID1 strain uses all the alternative carbon sources (sucrose, glycerol and cow's milk). According to some papers, LNB fast-growing species (Trinick MJ, 1980; Stowers and Eaglesham, 1984) and LNB intermediate growing species (Stowers and Eaglesham, 1983) can grow in LNB growth media containing sucrose as carbon source. Glycerol is adapted for LNB slow-growing species and for certain LNB fastgrowing species (Stowers and Elkan, 1984). When mannitol is replaced with $12.5 \mathrm{~g} / \mathrm{l}$ of glycerol in a LNB growth medium, a Bradyrhizobium strain showed a better growth (79\%) compared to YEM medium (Ormeno and Zuniga, 2008). Ding (2012) isolated the locus responsible for glycerol utilization from plasmid pRleVF39c in Rhizobium leguminosarum bv. viciae VF39. Yeast water allows a better growth with carbon sources than the other does. In the preparation of the medium, $100 \mathrm{ml}$ of yeast water was used with all the four carbon sources. These media contained $75 \mathrm{mg}$ of nitrogen. This could be the reason of the presence of yeast water in the preferred media of the two LNB strains. These differences on the growth of the two strains could be explained by the capacity of the strains to use different sources of carbon 


\begin{tabular}{l}
$\begin{array}{l}\text { Ngo Mimb et al. J. Appl. Biosci. 2014. Use of local substrates in production of legume nodulating } \\
\text { bacteria inoculants. }\end{array}$ \\
\hline
\end{tabular}

and nitrogen. Allen and Allen (1950) and Ben Rebah et al. (2007) showed that LNB which can grow on a large variety of carbon substrate are fast-growing bacteria. Although, in such media preparations, a single source of carbon cannot be used for all strains, because rhizobial strains of different genera often differ in carbon utilization (Tittabutr et al., 2005). These results can also be justified by the composition of these local carbon and nitrogen sources for LNB growth (Table 3).
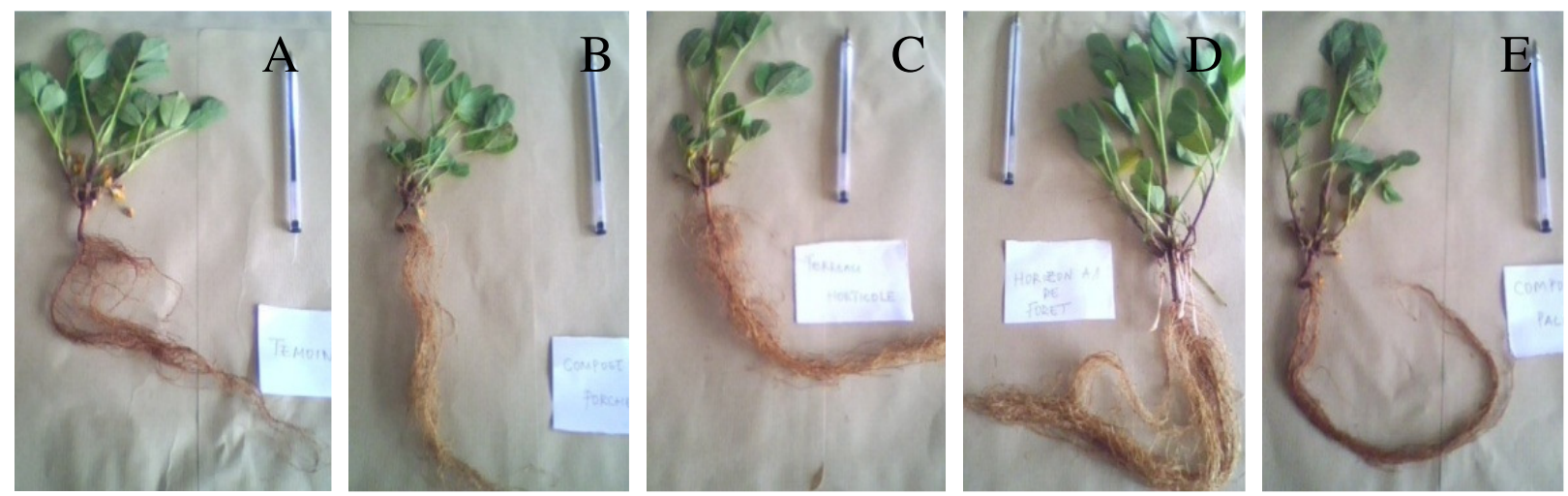

Figure 3: Fresh biomass of groundnuts plants inoculated with LNB inoculants. A. control, B. household organic compost inoculant, C. horticultural compost inoculant, D. forest humus inoculant, E. palm tree inoculant.

The same results were the same as with LNB biomass obtained by weighing after centrifugation. LNB biomass was also higher as OD after four days. Nwaga and Ngo Nkot (1998) have obtained a correlation between optical density and rhizobial biomass in the study of the growth of LNB strains at different $\mathrm{pH}$.

Effect of local products as carrier for LNB inoculants production: The results on the nodulation of groundnuts present significant differences between all the treatments. The best results concerning number of nodules, fresh and dry weight of nodules and nitrogen uptake were observed on groundnuts inoculated with LNB inoculant based on forest humus. Total nitrogen in the mixture soil/sand was $50 \%$ and infection and nodulation occurred on the roots of groundnuts. This amount of nitrogen allowed the nodulation and the fixation of nitrogen by the LNB contained in all the LNB based inoculant. There was no inhibition of nitrogen fixation by the leghemoglobin. The inhibitory effect of nitrate on nitrogen fixation was attributed to a direct competition between the nitrate reductase and nitrogenase for reducing power (Straub et al., 1997) or on the assumption that the nitrite intermediate of nitrate reductase inhibits the functioning of the nitrogenase or leghemoglobin (Becana and Sprent, 1987). Regarding the organic matter contained in the carriers, forest humus has the lowest amount $(65 \mathrm{~g} / \mathrm{kg})$. Also the lowest values were on total carbon $(38 \mathrm{~g} / \mathrm{kg})$, total nitrogen $(2.1 \mathrm{~g} / \mathrm{kg})$, phosphorus $(0.05 \mathrm{~g} / \mathrm{kg})$, calcium $(83.2 \mathrm{~g} / \mathrm{kg})$, magnesium $(37.2 \mathrm{~g} / \mathrm{kg})$ and sodium $(3.2$ $\mathrm{g} / \mathrm{kg}$ ). For example, when taking phosphorus amounts of the four carriers, it was noted that the higher this amount was, the lowest nitrogen uptake was observed. It means that, when using these two LNB strains (VUID1 and AHYP21) they cause infection, nodulation and nitrogen uptake when they grow well in the presence of a small amount of phosphorus. Phosphorus appears essentially for both nodulation and $\mathrm{N}_{2}$ fixation (Pereira and Bliss, 1989; Ssali and Keya, 1983). According to Lum and Hirsch (2003), when phosphorus is limited, the LNBlegume symbiosis does not occur. Amounts of phosphorus in all the LNB carriers are not limited and allow the LNB-legume symbiosis. The establishment of the symbiosis between groundnuts and LNB contained in the carrier based inoculants is effective and allows the development of groundnuts' biomass. An effect between $8 \%$ and $16 \%$ is observed on the dry biomass of inoculated groundnuts and between $39 \%$ and $127 \%$ on the nitrogen uptake. The best results were obtained with forest humus and they could be also justified by its moisture, water holding capacity and total organic matter amounts. These three elements were important to obtain a good carrier for LNB inoculants (Ben Rebah, et al., 2002). Viability of $L N B$ contained in the inoculants is not considered in this production. However, the results on nodulation are the response of the presence of viable LNB in this inoculant. According to these results, forest humus is the best carrier in this work. It has physicochemical characteristics that allow LNB growth and certainly a long viability. The other carriers can also be used in the LNB inoculants production. 


\section{CONCLUSION}

The contribution of local products in LNB carrier based inoculants production has allowed the evaluation of different organic matter sources for LNB culture growth and nitrogen fixation. Products generally used are expensive and the use of local available and inexpensive

\section{REFERENCES}

Allen EK, Allen ON. Biochemical and symbiotic properties of the rhizobia. Bacteriology Reviews. 1950;14: 273-330.

Bailey LD. Influence of single strains and a commercial mixture of Bradyrhizobium japonicum on growth, nitrogen accumulation and nodulation of two early-maturing soybean cultivars. Canadian Journal of Plant Science. 1988;69: 41-418.

Becana M, Sprent JL. Nitrogen fixation and nitrate reduction in the root nodules of legumes. Physiologia Plantarum. 1987;70: 757-765.

Ben Rebah F, Tyagi RD, Prévost D. Wastewater sludge as a substrate for growth and carrier for rhizobia: the effect of storage conditions on survival of Sinorhizobium meliloti. Bioresource Technology. 2002;83: 141-151.

Ben Rebah F, Prevost D, Yezza A, Tyagi RD. Agroindustrial waste materials and wastewater sludge for rhizobial inoculant production: A revew. Bioresource Technology. 2007;98: 35353546.

Chao WL, Alexander M. Mineral soils as carriers for Rhizobium inoculant. Applied Environmental Microbiology. 1984;47:94-97.

Crawford SL, Berryhill DL. Survival of Rhizobium phaseoli in coal-based legume inoculants applied to seeds. Applied Environmental Microbiology. 1983:45:703-705.

Daza A, Santamaria C, Rodriguez-Navarro DN, Camacho $M$, Orive R, Temprano F. Perlite as a carrier for bacterial inoculants. Soil Biology and Biochemistry. 2000;32:567-572.

Ding H, Yip CB, Geddes BA, Oresnik IJ Hynes MF. Glycerol utilization by Rhizobium leguminosarum requires an $A B C$ transporter and effects competition for nodulation. Microbiology. 2012; 158:1369-1378.

Ferreria EM, Castro IV. Residues of the cork industry as carriers for the production of legume inoculants. Silva Hustana, 2005;13: 159-167.

Graham-Weis L. Bennet ML, Paau AS. Production of bacterial inoculants by direct fermentation on nutrient-supplemented vermiculite. Applied products may reduce the prices of BNL carrier based inoculants. Studying the viability of LNB in local carrier and field experimentation using local legumes are two important steps in the confirmation of the interest of this technology.

Environmental Microbiology. 1987;53:21382140.

Hashem MM, Abdel-Moniem A. Evaluation of water hyacinth and sugarcane bagasse composts as a carrier for Rhizobium inoculants and their effects on faba bean. Research Journal of agriculture and biological sciences. 2010;6(6):1022-1028.

Khavazi K, Rejali F, Seguin P, Miransari M. Effects of carrier, sterilization method, and incubation on survival of Bradyrhizobium japonicum in soybean (Glycine max L.) inoculants. Enzyme and Microbiology Technology. 2007;41:780-784.

Kremer RJ, Peterson HL. Effects of carrier and temperature on survival of Rhizobium spp. in legume inocula: development of an improved type of inoculant. Applied Environmental Microbiology. 1983;45:1790-1794.

Kucuk C, Kivanc M. Preliminary characterization of Rhizobium strains isolated from chickpea nodules. African Journal of Biotechnology. 2008; 7(6):772-775.

Lum MR, Hirsch AM. Roots and their symbiotic microbes: strategies to obtain nitrogen and phosphorus in a nutrient-limited environment. Journal of Plant Growth Regulation. 2003;21:368-382.

Muniruzzaman S, Khan SI. Suitability of some local agroindustrial wastes as carrier materials for Rhizobium sp. infecting Sesbania bispinosa. World Journal of Microbiology and Biotechnology. 1992;8:329-330.

Nwaga D. Industrial production of rhizobial inoculants for legumes in Cameroon. Project to New England Foundation, USA. 1994; 9 p.

Nwaga $D$, Ngo Nkot $L$. Tolérance in vitro de rhizobia isolés de Vigna unguiculata au Cameroun en comparaison avec Bradyrhizobium japonicum. Cahiers Agricultures. 1998;7 : 407-410.

Nwaga, D, Ngonkeu MEL, Oyong MM, Ngakou A, Abelong MP, Foko J. Soil beneficial microorganisms and sustainable agricultural production in Cameroon: current research and perspectives. In: TSBF report 1997-1998. The biology and fertility of tropical soils. 2000;62-65. 
Ormeno E, Zuniga D. Modification of YEM broth for medium scale production of legume inoculants. Revista Peruana de Biologia. 1998;5(2):1-9.

Pereira PAA, Bliss FA. Selection of common bean (Phaseolus vulgaris L.) for N2 fixation at different amounts of available phosphorus under field and environmentally-controlled conditions. Plant Soil. 1989;115:75-82.

Singh AK, Singh G, Bhatt RP, Pant S, Naglot A, Singh L. Sugars waste, an alternative growth and complete medium for fast growing Rhizobium cells. African Journal of Microbiology Research. 2011; 5(20): 3289-3295.

Somasegaran P, Bohlool BB. Single-strain versus multistrain inoculation: effect of soil mineral $\mathrm{N}$ availability on rhizobial strain effectiveness and competition for nodulation on chickpea, soybean and dry bean. Applied and Environmental Microbiology. 1990;56: 3298-3303.

Somasegaran P, Hoben HJ. Methods in legumeRhizobium Technology. NifTAL Project and MIRCEN, Paia, Hawai-USA. 1985;365 p.

Ssali $H$, Keya SO. The effect of phosphorus on nodulation, growth and dinitrogen fixation by beans. Biological Agriculture and Horticulture, 1983.1:135-144.

Stowers MD, Eaglesham ARJ. A stem-nodulating Rhizobium with physiological characteristics of both fast and slow growers. Journal of General Microbiology. 1983 ; 129:3651-3655.
Stowers MD, Eaglesham ARJ. Physiological and symbiotic characteristics of fast-growing Rhizobium japonicum. Plant Soil, 1984 ;77 :314.

Straub PF, Shearer G, Reynolds PHS, Sawyer SA, Kohl D. Effect of disabling bacteroid proline catabolism on the response of soybean to repeated drought stress. Journal of Experimental Botany, 1997;48: 1299-1307.

Thompson JA. Legume inoculant production and quality control In: Report on the expert consultation on Legume inoculant Production and quality control. Thompson JA (Ed.). Rome. 1991;1-144.

Tittabutr P, Payakapong W, Teaumroong N, Boonkerd N. Cassava as cheap source of carbon for rhizobial inoculant production using amylase-producing fungus and a glycerol-producing yeast. World Journal of Microbiology and Biotechnology. 2005; 21: 823-829.

Trinick M J. Relationships among the fast-growing rhizobia of Lablab purpureus, Leucaena leucocephala, Mimosa sp., Acacia farnesiana, and Sesbania grandiflora and their affinities with other rhizobia groups. Journal of Applied Bacteriology. 1980;49:39-53.

Vincent JM. A manual for the practical study of root nodule bacteria. International Biological Programme. Handbook $\mathrm{N}^{\circ}$. 15. Oxford, UK, Blackwell Scientific Publications. 1970;164 p. 